\title{
Al-Turas
}

website : bit.ly/buletinalturas

\section{Conversational Implicature Analysis in "Kingdom of Heaven" Movie Script by William Monahan}

\author{
Saiful Akmal* \\ Universitas Islam Negeri Ar-Raniry \\ Banda Aceh, Indonesia \\ saiful.akmal@ar-raniry.ac.id \\ Desy Ulfa Yana \\ English First (EF) \\ Jakarta, Indonesia \\ desyulfayana@gmail.com
}

\begin{abstract}
This study was designed to discover the types of conversational implicature and the non-observance maxim of cooperative principles expressed by the characters in the Kingdom of Heaven movie script by William Monahan. The theory of Grice was applied to analyze the conversational implicature, and the qualitative approach is used to explain the conversational implicatures. After analyzing the movie, we discovered particularized implicatures as the most frequent conversational implicatures in the movie script with 14 occurrences, followed by six occurrences of generalized implicatures. The finding also revealed that the frequent use of flouting maxim of quantity occurred more frequent with 14 out of the total 20 excerpts, with violating maxim found only three times in the movie script. From this study, both findings suggested the reason behind the frequent use of flouting maxim compare to violating maxim in conversational implicature is because the speaker assumes that they will be in a safe position, and then expect the hearer to understand their points, as the speaker did not intentionally manipulate or mislead the hearer.
\end{abstract}

Keywords: conversational implicature; movie script; Kingdom of Heaven; William Monahan 
Saiful Akmal, Desy Ulfa Yana,

\section{Abstrak}

Penelitian ini bertujuan menemukan jenis-jenis implikasi percakapan yang dihasilkan dari prinsipprinsip non-observance maxim, dan mendiskusikan makna implikasi-implikasi yang diungkapkan oleh karakter-karakter dalam film Kingdom of Heaven. Teori Grice digunakan untuk menganalisis implikatur percakapan dan desain kualitatif digunakan untuk menjelaskan implikatur percakapan. Setelah menganalisis film, kami menemukan implikatur percakapan yang paling sering terjadi atau digunakan dalam skrip film adalah implikatur khusus sebanyak 12 kali, diikuti oleh implikatur umum dengan 6 kali frekuensi. Penelitian ini juga menemukan bahwa flouting maxim of quantity ditemukan lebih banyak (14 kali dari 20 temuan) dibandingkan violating maxim (3 kali) adalah karena pembicara berasumsi bahwa maksud dari kalimat yang mereka sampaikan tidak menimbulkan pertikaian secara langsung namun secara tersirat dan mengharapkan pendengar untuk memahami maksudnya. Ini berbeda dengan violating maxim, dimana pembicara sengaja menggunakan manipulasi dalam implikatur percakapan kepada pendengar

Kata kunci: Implikatur percakapan; skrip film; Kingdom of Heaven; William Monahan

\section{الملخص الأنار}

تهدف هذه الدراسة إلى العثور على أنواع الآثار المنرتبة على المحادثة الناتجة عن مبادئ

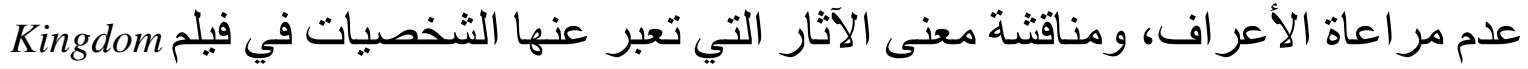
of Heaven

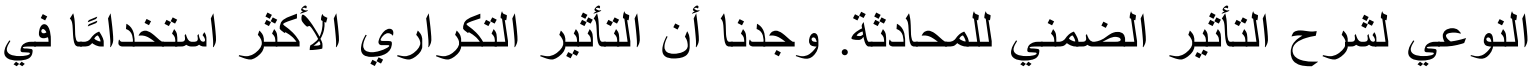

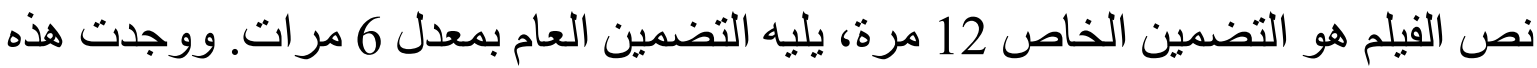

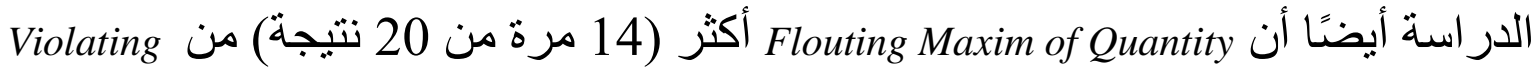
(3 Maxim

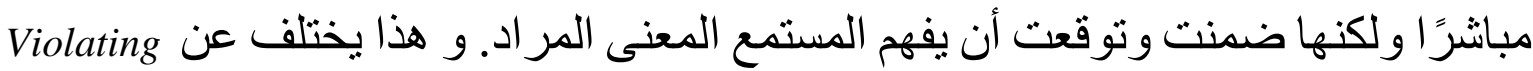

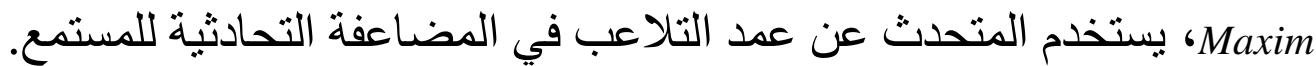
الكلمات الرئيسية: آثار المحادثة؛ سيناريو الفيل؛ Kingdom of Heaven؛ وليام موناهان 


\section{INTRODUCTION}

\section{Background}

Language is a tool for human being to communicate in order to survive and interacting minds (Sirbu, 2015; Tylén et al., 2010). As we know that communication is the most important part to live the life. Obviously, it cannot be denied that language plays a very important role in communication (Hang, 2013, p. 1). Amberg and Vause (2009, p. 2) pointed out that "language is primarily a means of communication, and communication almost always takes place within some sort of social context". There are many functional ways of communication yet language is its essentials unit. When people be acquainted with language, they can use it to deliver and exchange messages, convey ideas, express feelings and to maintain their social relationship as well as their life. According to Mohamed (2016, p. 53), people are able to exchange knowledge, beliefs, opinions, wishes, threats, commands, thanks, promises, declaration, feeling, we also can express our feeling, and so on, but our system of communication before anything else is language. Hence, language is the key point in communication. A good and effective communication needs a good understanding and connectivity between language and the users.

However, culturally, instead of delivering a message through communication directly, sometimes we say it in an indirect way (Beth Fisher-Yoshida \& Geller, 2012). Moreover, the symbol the speakers use in conversation in the communication not only refers to their subject but also to carry out the meaning. Therefore, in some condition of human communication, the words utter more than what they said. Hang (2013) said that every utterance is seen as communicating a variety of proposition, some explicitly, others implicitly. Many language users use language based on their needs as there is no accurate and internationally agreed rules in using language (Martini, 2018). Regarding this issue, Gadzar (1979), as stated in Chapman and Clark, said that pragmatics relate to the meaning of utterances which cannot be accounted for by straight forward reference to the truth condition of the sentence uttered (2014, p. 118). In relation to this issue, implicature is the domain of pragmatics which scrutinizes the meaning in speaker's utterance is not like what being said, and very often linked to the sense or level of speaker's politeness or impoliteness in communication (Haugh, 2014).

Grice (1967) introduced the term "implicature" to refer to the intended implications of an utterances (Hang, 2013, p. 1). The term "implicature" is used by Grice (1975) to account for what a speaker can imply, suggest, or mean, as distinct from what the speaker literally says (Brown et al., 1983, p. 31). Hang points out that in implicature which one says and communicates one thing yet he or she communicates something in addition, it is called conversational implicature. Brown et al. also point out that the notion of conversational implicature which is derived from a general principle of conversation plus a number of maxims which speakers will normally comply with, the general principle is called the "cooperative principle" (1983, p. 31). Notwithstanding, Hang argues that even though conversational implicatures are one of the central topics in semantics and pragmatics, yet it seems that we know much more about them in theory than practice $(2013$, p. 2$)$.

It is important to understand the implications of the utterance to prevent misunderstanding and to know what the meaning that speaker wants to address in communication. Understanding implicature, especially conversational implicature in communication is very important. The conversational implicature could possibly take place in daily conversation naturally (Martini, 2018). So, as a language learner, Ifantidou (2013) said that recognizing conversational implicatures and responding to it felicitously can be 
regarded as a language learners' pragmatic competence. Or else, it is a reflection on how explicit are the instruction in language learning.

Studies on the analysis of conversational implicature are numerous (Risdianto, 2011; Xiaosu, 2010), let alone the study of the analysis between, movie and languages or social critics (Forchini, 2013; Lestari et al., 2020). Some focus on specific linguistic analysis of cartoons (Bright, 2013; Kondowe et al., 2014), movies (Hadiati, 2018; Huda, 2013), TV shows and series (Jafari, 2013; Kaloeti, 2012; Lubis, 2017), and other form of written texts (Igwedibia, 2017; Slocum, 2016). Some studies also emphasized more on movie scripts, like this present study, for example, the work from Kustantini (2012), Dewiyana (2019), or Agustina (2018). All the above-mentioned studies have shed light on how conversational implicature were used by the characters in the movies to acknowledge the centrality of this concept in our life.

Therefore, in this present study, we would like to uncover the conversational implicatures in communication the Kingdom of Heaven's movie script as source of data. In accordance with above statements in the background, the writer would like to uncover the information of conversational implicature types are frequently found in Kingdom of Heaven movie script by William Monahan and non-observance maxim of cooperative principle categories recurrently found in conversational implicature in Kingdom of Heaven movie script by William Monahan.

\section{METHOD}

In this study, we used qualitative approach for data collection and analysis. Qualitative research is a generic term for an extensive selection of approaches and methods for the study of social life (Saldana, 2011). Additionally, Newman (2014) argued that qualitative approach looks at interpretation or the creation of meaning in specific setting. We therefore used qualitative content analysis method to interpret the speaker's utterance contained in the movie script as we used selected textual data or text-based linguistic data for this study, following the idea from Stemler (2015).

The source of the data was taken from The Kingdom of Heaven movie script by William Monahan. Kingdom of Heaven is a historical drama movie directed and produced by Ridley Scott and the script is written by William Monahan. This Movie was officially out in 2005. This movie is a story set during the Crusades of the 12th century. Kingdom of Heaven is about an ordinary man who finds himself thrust into a decades-long war. A French village blacksmith goes to the Kingdom of Jerusalem and defense against Ayyubid Sultan, Saladin, who claim the city from Christian leading to the Battle of Hattin. He must protect the people of Jerusalem from overwhelming forces-while striving to keep a fragile peace. We will analyses the conversations in the script by using pragmatics tool of Grice conversational implicature.

Basically, the writer used these steps for collecting following Huberman and Miles qualitative data analysis (2014). First, the textual analysis towards the script was done by reading the whole movie script by William Monahan and identify the conversations in the script which contained conversational implicatures. The writer served the data found into the table, so it can be seen which data is found frequently. Afterward, using Grice's theory about implicatures (1975), the writer described the data finding in the data description about the types of conversational implicatures and non-observance maxim mostly found in the Kingdom of Heaven movie script by William Monahan.

The data analysis in this study used the pragmatics theory by Grice (1975) about implicatures, especially the type of conversational analysis and the non-observance maxims. 
The types of conversational implicatures and the non-observance maxim were analyzed to find what are the most frequently found in the data. The selected data were analyzed based on Miles and Huberman's theory (2014) in three major phases which are data reduction, data display and conclusion drawing and verification. Reducing the data, we organized the conversation in the movie and the script based on Grice's theory about implicatures. We selected, simplified and transformed the data that appeared in the movie script to address the issue. Displaying the data by using intra-case display as we have assumed that most characters failed to observe the same maxim. We assembled the selected data to analyze them one by one in the discussion on conversational implicatures from the utterance in the characters conversation. Conclusion, drawing and verification. We concluded which types of conversational implicatures and non-observance maxim mostly found in the characters in The Kingdom of Heaven Movie Script. In verification stage, we revisited and cross-check the data before generating conclusion.

\section{FINDINGS AND DISCUSSION}

After analyzing the data, we found the conversational implicature in the Kingdom of Heaven Movie script by William Monahan performed by the characters in the movie. The analysis, finding and discussion of this study will be particularly focused on the cooperative principles in conversational implicature as well as its non-observance maxim and thus, leave the conventional implicature out of the context of this study. The data finding is served in Table. 1

Table 1. The Type of Conversational Implicature and the Non-Observance Maxims Found in Kingdom of Heaven Movie Script

\begin{tabular}{cllll}
\hline $\begin{array}{c}\text { No. } \\
\text { data }\end{array}$ & $\begin{array}{l}\text { Types of } \\
\text { Implicature }\end{array}$ & $\begin{array}{l}\text { The non- } \\
\text { observance }\end{array}$ & Maxims & $\begin{array}{c}\text { Time played in the } \\
\text { movie }\end{array}$ \\
\hline 1. & Particularized & Flouting & Manner & $02: 34-02: 51$ \\
2. & Particularized & Flouting & Relation & $04: 47-04: 51$ \\
3. & Generalized & Violating & Quality & $04: 59-05: 04$ \\
4. & Particularized & Violating & Manner & $06: 36-06: 47$ \\
5. & Generalized & Flouting & Manner & $08: 24-08: 42$ \\
6. & Particularized & Flouting & Relation & $13: 11-13: 22$ \\
7. & Particularized & Flouting & Quantity & $13: 24-13: 35$ \\
8. & Particularized & Flouting & Quantity & $16: 42-16: 53$ \\
9. & Particularized & Flouting & Manner & $21: 46-21: 56$ \\
10. & Generalized & Flouting & Quantity & $56: 20-56: 28$ \\
11. & Particularized & Flouting & Quantity & $58: 06-58-25$ \\
12. & Particularized & Flouting & Quantity & $01: 00: 32-01: 00: 52$ \\
13. & Generalized & Flouting & Quantity & $01: 13: 06-01: 13: 10$ \\
14. & Particularized & Flouting & Quantity & $01: 14: 40-01: 14: 48$ \\
15. & Particularized & Flouting & Quantity & $01: 32: 54-01: 33: 30$ \\
16. & Generalized & Flouting & Quantity & $01: 45: 15-01: 45: 41$ \\
17. & Particularized & Flouting & Manner & $01: 45: 45-01: 46: 32$ \\
18. & Particularized & Flouting & Manner & $02: 33: 36-02: 33: 35$ \\
19. & Generalized & Flouting & Relation & $02: 37: 30-02: 37: 34$ \\
20. & Particularized & Flouting & Manner & $02: 46: 19-02: 46: 53$ \\
\hline
\end{tabular}

As it can be seen in the table, particularized implicatures were found more frequently with 14 from 20 occurrences in the movie script, while generalized implicatures were four occurrences. Then, it is served in table 1 of what type of non-observance maxims was found frequently. It can be seen from table 1 that the characters of the movie frequently flouted the 
maxims of quantity with nine occurrences from 20 data, then followed by flouting the maxim of manner with seven occurrences; flouting the maxim of relation with three occurrences, and violating the maxim of quality with only one occurrence.

\section{Particularized Implicature}

\section{Flouting Maxim of Manner}

There were seven conversations that contained flouting maxim of manner; however, the discussion only covers some interesting ones. It began with the conversation that occurred between the priest and the gravedigger as data one. The gravedigger was watching for his chance in life long after he should have stopped looking. His right ear was mutilated.

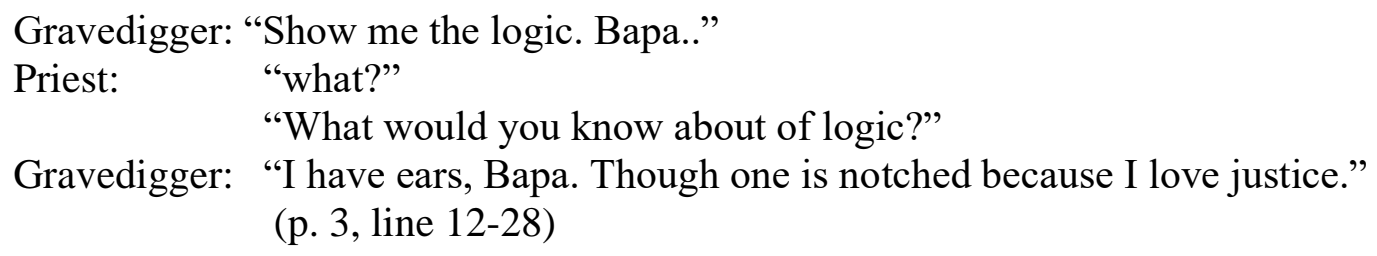

From the conversation above, the utterance of the gravedigger "I have ears, Bapa. Though one is notched because I love justice" represented a particularized implicature because we need to know the context to get what the gravedigger tried to deliver. He was precariously flouted maxim of manner by not being clear that he knew what happened with woman. According to Kaloeti (2012), in this case, specific context was required to generate meaning of the given particularized implicature. A similar context was also found in data nine that referred to the conversation between the priest and the old guard when tried to give sympathy to Balian who had no farmworker because of his wife. Here is the conversation.

Priest: "The bishop needs you", "Release him"

Old guard: "On your feet. This is not heaven. It is the world, and there are troubles in it. Do yourself no injury. Other men are always good for that."

(p.8, line 17-28)

In this context, particularized implicature emerged as we need to generate the meaning to get what they were trying to say to Balian. The old guard flouted the maxim of manner by not being brief that he meant to ask Balian to join the Godfrey. Such situation implicates special knowledge on the utterance, or in the word of Levinson (2000, p. 126), the special features of the context. In the same context, the following conversation as data 17 took place between the king, Balian and Tiberias. The king asked him to marry his sister, Sibylla.

The king: "Would you marry Sibylla when she is free of Guy de Lusignan?"

Balian: "And Guy?"

Tiberias: "He will be executed along with his knights who do not swear to you."

Balian: "I cannot be the cause of that."

Tiberias: "Whatever you ask, I will serve."

Balian: "A king man moved a man, you said. But the soul, belongs to the

man."

The king: "Yes I did."

Balian: "You have my love and my answer."

The king: "So yeah" (p. 89, line 12-38) 
Balian's utterance of "a king man moved a man, you said. But the soul, belongs to the man" and he added "you have my love and my answer" rising a particularized implicature. He flouted the maxim of quantity. He said that instead of saying he did not want to marry Sibylla. But he knew that from his utterance, the king could assume that he did not want to do that. It showed from his utterance of "you have my love and my answer." It is a particularized implicature because we need further analysis to understand the context of the conversation above. The context why the king asked Balian to marry Sibylla was because he knew that Guy de Lusignan was not the right person to replace him. The general result was also in accordance with Mukaro et al. (2013) that flouting a maxim, like the one mentioned here was used to avoid an uncomfortable situation.

Data 18 was about the conversation between Saladin and his knight. It happened when they attacked the Jerusalem after it fell under Guy de Lusignan's control. At that time, Jerusalem was taken back and Saladin asked whose control it was.

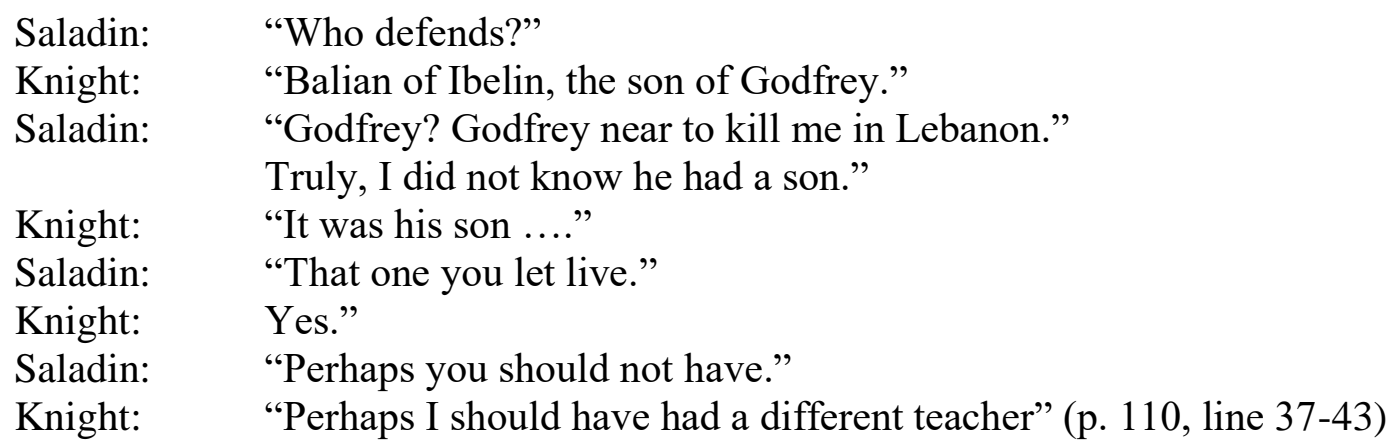

The utterance of the knight of Saladin "perhaps I should have had a different teacher" to create an implicature. He was uncooperative because he flouted the maxim of manner. His answer did not directly relate to what the topic they talked about. Moreover, it counts as a particularized implicature because we need to generate why the knight said that. Additionally, he said that because what he did was influenced by his teacher, Saladin. Lestari (2020) argues that conflictive reason, as the one found here, can be the main reason of flouting the maxim.

\section{Flouting Maxim of Quantity}

Flouting maxim of quantity arouse in the conversation included nine occurrences; however, the discussion only covers six of them. The following conversation between Odo and Balian as data seven was assumed to have flouting maxing of quantity. Here it is.

Odo: "Against whom and for whom did you fight?"

Balian: "For one lord against another, on a point which cannot be remembered, and which is then or now had no significance." (p. 14, line 1-8)

From the conversation above, the utterance of Balian "for one lord against another, on a point which cannot be remembered, and which is then or now had no significance" was an evidence of a particularized implicature. He was clearly being stubborn by flouting the maxim of quantity. Balian bluntly did not give the information as it is required. It is a particularized implicature because we need to generate the context and what Balian actually talked about. This is in line with Pop (2010) argument that flouting a maxim is often counting on contextual assumptions of the listener. The same context was also found in data eight that 
was the conversation between Godfrey, the Baron of Ibelin, and Balian. After telling the truth that he was the father of Balian, Godfrey asked Balian to go with him to Jerusalem.

Godfrey: "If you will come with me you will have a living. You will have my thanks. There, it is." (p. 15, line 40-42)

Balian: "Whoever you are, my lord, and whatever you are saying, my place is here." (p. 16, line 1-4)

In the conversation, the utterance of Balian "whoever you are, my lord, and whatever you are saying, my place is here" was not cooperative. He flouted the maxim of quantity. His utterance means that he did not want to go to Jerusalem with Godfrey. To know the implicature, we need to know the context that Balian lived in France and he did not want to go to Jerusalem because he was still mourning the death of his wife. In the same vein, Sadehvandi (2011) verifies that the speaker in such cases demand listener's maximum understanding to unlock the hidden meaning of what is being said.

Another conversation that contained flouting maxing of quantity was also found in data 11. It was the dialogue between Tiberias and Muslim grandee after they talked with Reynald that Muslim Grande was a witness of Reynald's raid.

Tiberias: "I cannot protect your caravans unless you agree to be escorted by our soldiers."

Muslim grandee: "I trade to make money. Not to offend God by associating with Christians." (p. 45, line 16-24)

The utterance of the Muslim grandee rises a particularized implicature as we have to know the context from his utterance. The context was that the Muslim who witnessed Raynald's raid tried to make money and he did not want to join the Christian just because of the protection from the kingdom. He flouted the maxim of quantity by not giving the information as it is required from his utterance Tiberias knew that he and his caravans did not want to be escorted by their soldiers. Further evidences provided by Livnat (2011) indicated that flouting a maxim of quantity like occurred in this excerpt was not only a gist of unforeseen meaning, but also a tool to expose an untruthfulness or ironic effect found in certain components of the statements. A similar context was also found in data 12 that was the conversation between Tiberias and Balian when Tiberias told him about his father, Godfrey.

Tiberias: "What did your father tell you of your obligations?"

Balian: "That I was to be a good knight."

Tiberias: "I pray the world and Jerusalem can accommodate such a rarity as a perfect knight." (p. 47, line 7-16)

From Tiberias's utterance of "I pray the world and Jerusalem can accommodate such a rarity as a perfect knight", It rising the Particularized implicature as we have to generate the context that he flouted the maxim of quantity. He meant that he did not know whether Balian will be a good knight or not because it was very rare to find a perfect knight in Jerusalem. He implicated the meaning instead of saying "I hope you will be a perfect knight". In this case, Alduais (2012) believed that in conversational implication, flouting the maxims clearly pointed to the fact that what was said was not what was meant.

Complementarily, another conversation (data 14) also resulted particularized implicature. It happened between Balian and Sibylla after they are having food and Balian asked her about her marriage with Guy. Here it is. 

Balian:
"Did you decide on Guy?"
Sibylla:
"Guy was chosen by my mother." (p. 55, line 29-33)

The conversation above clearly promotes an implicature. Sibylla was uncooperative by flouting the maxim of quantity. Instead of saying "I didn't choose Guy," she said "Guy was chosen by my mother." But she knew that Balian identified what she actually meant. The particularized implicature happens because we need to know the context. To understand the utterance of Sibylla, it needs to be generated. Sibylla said that because her first husband died when she was pregnant and her mother chose Guy de Lusignan to be her husband and she could not refuse it. This is similar to Hasan (2015) finding that being obscured and or giving little information were among the strategies used by speakers in flouting the maxim.

In data 15, that was the conversation between the Saladin and the king, a particularized implicature was also found. The conversation happened when both of them rode to meet in the middle of Jerusalem and Damascus. They talked in front of their army about war lured by Guy de Cantillon.
Saladin:
"I pray you pull back your cavalry and leave this matter to me."
The king:
"I pray you retire unharmed to Damascus. Reynald de Chatillon will be punished. I swear it. Withdraw, or we all die here. Do we have terms?"
Saladin:
"We have terms." (p. 79, line 8-38)

The utterance both of Saladin and the King "I pray you pull back your cavalry and leave this matter to me" and "I pray you retire unharmed to Damascus" was bluntly uncooperative and flouted the maxim of quantity. Both of them knew that each of them could assume what it meant. The particularized implicature happened because the context needed to be generated to understand what they actually talked about. The context was that both of them took a decision whether the war should be continued or not. From the utterance of the king "Do we have terms?" and Saladin answered "we have terms", then both of them agreed to return to their own place and temporarily stopped the raging war. The abovementioned conversational exchanges support Rundquist (1992) study that flouting maxim is all about indirectness.

Flouting maxim of quantity was also found in data 16. It happened when the queen wanted to meet Balian. Then, Sibylla took him to meet the king. They talked when they were in a corridor way to the king's room.

$$
\begin{array}{ll}
\text { Sibylla: } & \text { "Do you fear being with me?" } \\
\text { Balian: } & \text { "No... and yes." } \\
\text { Sibylla: } & \text { "A woman in my place has two faces. One for the world, and one } \\
& \text { which she wears in privacy. Then with you, I will be only } \\
& \text { Sibylla."(p. 50, line 11-20) }
\end{array}
$$

The utterance of Sibylla "a woman in my place has two faces. One for the world, and one which she wears in privacy. Then with you, I will be only Sibylla." She was disobliging by flouting the maxim of quantity. She did not say the information as it was needed. From the utterance, she meant that Balian did not have to be afraid of her. She knew that Balian could accept her utterance. Its context referred to a situation when Sibylla said that she was the queen of the kingdom and when she said that she stood as her own self, and not as the queen. We need to generate the context to understand the actual meaning of Sibylla's utterance and why she said that. So, the particularized implicature happened. In this context, the speaker 
used collaborative reason to flout the maxim as had been found by Fatmawati (2015) in her study.

\section{Flouting Maxim of Relation}

There were two conversations considered to contain flouting maxim of relation. The first referred to data two. It was a conversation between a bishop and a priest when they walked while talking about Balian and his suicide wife.

Bishop : "Your brother, you have spoken to him?"

Priest: "He is insane with grief, my lord, and still arrested." (p. 5, Line 22-

From the conversation above, the utterance of the priest was demonstrating a conversational implicature. He did not perceive the cooperative principle as he flouted the maxim of relation by not giving a relevant information. Nonetheless, he knew that the bishop could assume his implicit meaning from his utterance that he had not uttered to him. As in the context the Priest said that Balian was arrested because of his suicide wife, so that the Priest could not talk to him. To understand what he meant, we need to identify the context and it must be particularized implicature. This example exemplified the use of pragmatic reasoning to draw listeners' attention in flouting maxim of relation, as explained by Westera (2013).

The second was data six that referred to the conversation between Odo and Balian at Balian's home when he made their horses shot. Odo came and sat in front of him having the following dialogue.

Odo: "Have you been at war?"

Balian: "On horse, and as an engineer also.” (p. 13, line 29-39)

The conversation above showed that Balian did not observe the cooperative principle in his conversation. His utterance of "on horse, and as an engineer also" rose a conversational implicature. He flouted the maxim of relation as his answer did not relate to the question because Odo didn't ask where he was on that war. But he knew that by answering that, Odo got his point that he had been at war. In addition, he violated the maxim of quantity by not giving the specific answer of the war. Balian's reply evidently express the use of truthfulness to be relevant in the conversation (Wilson, 1995)

\section{Generalized Implicature}

\section{Flouting Maxim of Manner}

Flouting maxing of manner arouse in two conversations. The first was data five that comprised the conversation between Saladin and Balian after the second war ended. After Balian had defended the city, and Saladin came to meet him somewhere between Jerusalem and Damascus to have a term. The conversation was as follows.

Saladin: "when you yield the city?"

Balian: "Before I lose it, I will burn it to the ground. Your holy places, ours. Every last thing in Jerusalem that drives men mad."

Saladin: "I wonder if it would not be better if you did. You will destroy it?"

Balian: "Every stone. And every Christian knight you kill will take ten Saracens with him. You will kill your army here and never raise another. 
(p. 119, line 25-43)

I swear to God if you take this city, will be the end of you." (p.120, line 1-3)

From the conversation above, the utterance of Balian "Before I lose it, I will burn it to the ground. Your holy places, ours. Every last thing in Jerusalem that drives men mad" and "And every Christian knight you kill will take ten Saracens with him. You will kill your army here and never raise another. I swear to God if you take this city, will be the end of you" clearly demonstrated the conversational implicature. Balian was being stubborn by flouting the maxim of manner (Sobhani \& Saghebi, 2014). From his utterances, it can be seen that he was doing prolixity by saying that. He actually meant that there would be a war before he yielded the city.

The second referred to data 20 that concerned with the conversation that happened when Balian decided to go with Godfrey to Jerusalem. He took his horse and found Godfrey in the middle of nowhere in France. See the following conversation.

Balian: "Is it true that it, Jerusalem I can erase my sins and those of my wife? Is

$$
\begin{array}{ll} 
& \text { true?" } \\
\text { Godfrey: } & \text { "We can find out together." (p. 18, line 15-20) }
\end{array}
$$

The utterance of Godfrey in conversation above did not obey the cooperative principle. He flouted the maxims of manner as his answer gave the ambiguity (Taghiyev, 2017) whether Balian could erase his sins and those of his wife or not. It must be generalized implicature because from the utterance we need to know the context that Godfrey did not actually know whether sins could be erased or not in Jerusalem because the main reason for him to go to Jerusalem was the kingdom.

\section{Violating Maxim of Manner}

There was one violating of manner as seen in data four. It contained the conversation between Godfrey and his brother when they were dining together and trying to find out what happened in Jerusalem. Here is the conversation.
Godfrey:
"Which son of the blacksmith of my time is the blacksmith now?
His brother:
"The Eldest, Balian. His child died. His wife fell into a melancholy. She would not listen to reason. She killed herself. It occurs. But what's that to you?"
Godfrey:
“A private matter" (p. 11, line 6-18)

Godfrey's statement "a private matter" represented a generalized implicature that we do not need any specific context to generate his meaning. Godfrey meant that it was private and he could not tell it to anybody. Yet, he clearly violated the maxim of manner by giving an ambiguous statement. The finding typified the use of flouting maxim to avoid judgment and prompt personal understanding from the listener toward the statement (Kondowe et al., 2014).

\section{Flouting Maxim of Quantity}

This maxim of quantity was found in data 10 that contained the conversation happened between Balian and Sibylla in Ibelin at Balian's room trying to clean the dirt of mud on Balian's face. Here is the conversation. 
Balian: "Did they give you something to eat?"

Sibylla: "It is to wait until the master return." (p. 61, line 24-33)

Sibylla's utterance of "it is to wait until the master return" was clearly uncooperative. She flouted the maxim of quantity as she did not answer Balian as she would answer directly to the point. Without having to generate the context of the conversation above, we understand the actual meaning of Sibylla's utterance that she did not get something to eat yet. So, it is definitely a generalized implicature. Therefore, this creates a distinction between what is said and implicature (Carston, 2008).

The same context was also found in data 13. It was a conversation between the King and Balian. Balian came to the king's room because the king wanted to ask him to take the kingdom with him. Here is their dialogue.

The king: the time has come to conclude my affairs. (p. 88, line 28-29)

If I leave the army with Guy, he will take power through my sister and make war on the Muslims. We have decided that you shall take command of the army of Jerusalem. Will you defend my nephew when he is a king?

Balian: $\quad$ Whatever you ask, I will serve. (p. 89, line 3-11)

Balian's reply indicated that he flouted the generalized implicature of maxim quantity. From his utterance, we know that he wanted to defend the king's nephew. Instead of saying "I will", he said "whatever you ask, I will serve." It meant that he would do whatever the king asked him to do. Levinson, Stephen and Levinson (2000) underlined that this type of example fell into the presumptive meaning of generalized implicature.

\section{Violating Maxim of Quality}

This kind of violating maxim of quantity was obtained in data three that referred to the conversation between the bishop and priest. They continued to talk about the burial of Balian's wife as follows.

$\begin{array}{ll}\text { Bishop: } & \text { "The burial was..." } \\ \text { Priest: } & \text { "Yes." } \\ \text { Bishop: } & \text { "Yet you did not mutilate the person." } \\ \text { Priest: } & \text { "No." (p. 5, line 28-38) }\end{array}$

The utterance of the priest "no" clearly rose the conversational implicature because he violated the cooperative principle of maxim quality by not giving the true information. He knew that it was his fault, because he did so. He asked the grave digger to mutilate Balian's wife by cutting off her head. The implicature from the conversation above must be a generalized implicature because we know that what "no" really means. Moreover, without any specific knowledge and context, we can understand that his utterance of "no" is the answer to the question whether he mutilated the body or not.

\section{Flouting Maxim of Relation}

There was only one data representing the floated maxim of relation. It was the conversation between Sibylla and the gravedigger (data 19). It happened when the gravedigger was injured after the attack, and Sibylla tried to medicate his hand. See the dialogue below. 
The gravedigger:

Sibylla "you are not a nurse."

:"we are what we do." (p. 115, 9-15)

From the conversation, Sibylla's utterance rose an implicature. She was uncooperative by flouting a maxim of relation. As the gravedigger said that she was not a nurse, Sibylla gave a statement which did not explicitly relate to what the gravedigger talked about. But she knew that from her utterance, the gravedigger could assume what she meant. She meant that she was not a nurse; however, as she cured him at that time, she could be a nurse. Alduais (2012) suggested that this type of generalized implicature was flouting the maxim of relation by deliberately adjust the main topic of conversation.

\section{CONCLUSION}

The present study aimed at identifying types of conversational implicature and its nonobservance maxim frequently occurred in Kingdom of Heaven movie script. Based on the findings, the two types of conversational implicature under Grice theory, generalized and particularized implicature, were found in this movie script. However, the number of these types found very imbalanced by, where the particularized implicature found more frequently than generalized implicature. Furthermore, the findings revealed that most of the nonobservance maxim was flouting the maxim of quantity. It happened because many of the characters in the movie gave the information as not it was required but they knew the audience or the hearer understand what they meant, so most of them flouted the maxim of quantity. The findings of this study are unique compared to the findings of Sudarni (2011) who differently found that the characters in the Salt movie used more varied maxims in conversational implicature to have more colorful meaning. However, this finding is in fact similar to what have been examined in Muvida (2015) work that the three main characters in Hotel Transylvania movie used more particularized implicature since the hearers did not need to ask for confirmation as they have understood the context very clearly, for the most part sacrificing own feeling for someone happiness.

Additionally, the non-observance maxims found in the data are flouted and violated. By referring to the literature review section, there is a difference between flouting and violating. According to Cutting (2005), the speaker is flouting the maxim when he/she anticipates the hearer to appreciate the meaning inferred, and assumes the hearer can understand the implicit meaning. In his study, Setiawan (2013), disclosed that most flouted maxim in conversational implicature is done by means of giving unclear and ambiguous replies to questions. This is relevant to the current study in which more answers of the questions were disguised to create the sense of politeness, and hedging in the so -called "royal context", has also been noted in the study conducted by Adawiyah (2016) and Rokhmania (2012). While violating the maxim happens because the speaker recognizes that the hearer does not see the reality, and will only recognize the shallow denotation of the words. With regard to the violating the maxim, this study confirms Nugraha (2013) argument that one of the reasons for violating the maxim is to clarify something to the hearer.

Moreover, the most frequent maxim found by the writer is the maxim of quantity which meant that the characters of the movie failed to observe it, because the contribution of the information were insufficient and less-informative than it was required. Then, it is followed by the maxim of manner which the speakers in the movie failed to also observe and thus it gave the sense of ambiguity and proximity. Then, the maxim of relation which showed that the speaker did not give the relevant information. Last, it was the maxim of quality, whereby 
the speaker did not notice because of false information. Under above explanation, the most noticeable finding was the mounting number of particularized implicature because the flouting maxim of quantity. It showed that the characters of the movie gave less or more information than it was required. We would also argue that the typical historical nuance as well as the genre of the movie seemingly another reason why these findings occurred.

\section{REFERENCES}

Adawiyah, R. (2016). Flouting Maxim Used by the Main Characters in "Focus" Movie [PhD Thesis]. Universitas Islam Negeri Maulana Malik Ibrahim.

Agustina, D. S. (2018). Conversational Implicature in Movie Script Tangled [PhD Thesis]. UIN Sunan Gunung Djati Bandung.

Alduais, A. M. S. (2012). Conversational Implicature (flouting the Maxims): Applying Conversational Maxims on Examples Taken from Non-Standard Arabic Language, Yemeni Dialect, an Idiolect Spoken at Ibb City. Journal of Sociological Research, 3(2), 376-387.

Amberg, J. S., \& Vause, D. J. (2009). American English: History, Structure, and Usage. Cambridge University Press Cambridge

Beth Fisher-Yoshida, \& Geller, K. D. (2012). Communicating Across Cultural Differences: Transnational Leadership. AMACOM.

Bright, F. O. (2013). Verisimilitude in Editorial Cartoons from Punch Newspaper: A Pragmatics Analysis. Strength for Today and Bright Hope for Tomorrow, 13(5), 43.

Brown, G., Brown, G. D., Brown, G. R., Gillian, B., \& Yule, G. (1983). Discourse Analysis. Cambridge university press.

Carston, R. (2008). Thoughts and Utterances: The Pragmatics of Explicit Communication. John Wiley \& Sons.

Chapman, S., \& Clark, B. (2014). Pragmatic Literary Stylistics. Palgrave Macmillan.

Cutting, J. (2005). Pragmatics and Discourse: A Resource Book for Students. Routledge.

Dewiyana, S. L. (2019). An analysis of Conversational Implicature in Avengers: Age of Ultron movie script [PhD Thesis]. UIN Sunan Gunung Djati Bandung.

Fatmawati, S. N. K. (2015). A Pragmatic Analysis of Maxim Flouting Performed by Solomon Northup in 12 Years a Slave Movie. Sastra Inggris-Quill, 4(1), 1-10.

Forchini, P. (2013). A Diachronic Study of Familiarizers ('man', 'guys', 'buddy', 'dude') in Movie Language. Perspectives, 21(4), 504-525.

Grice, H. P. (1975). Speech Acts. Syntax and Semantics, 3, 41-58.

Hadiati, C. (2018). The Speech Acts and Conversational Implicature of Wise's the Sound of Music. Leksika: Jurnal Bahasa, Sastra Dan Pengajarannya, 3(2).

Hang, L. T. (2013). An Investigation into Implicatures in Romeo and Juliet by William Shakespeare. Danang.

Hasan, R. (2015). Ways of Saying: Ways of Meaning: Selected Papers of Ruqaiya Hasan. Bloomsbury Publishing.

Haugh, M. (2014). Im/politeness implicatures. Walter de Gruyter GmbH \& Co KG.

Huda, M. (2013). Conversational Implicature Found in Dialogue of Euro Trip Movie. Jurnal Ilmiah Mahasiswa FIB, 3(1).

Ifantidou, E. (2013). Pragmatic Competence and Explicit Instruction. Journal of Pragmatics, 59, 93-116.

Igwedibia, A. (2017). Grice's Conversational Implicature: A Pragmatics Analysis of Selected Poems of Audre Lorde. International Journal of Applied Linguistics and English Literature, 7(1), 120-129. 
Jafari, J. (2013). The Pragmatic Analysis of Wilde's Comedy: The Importance of Being Ernest. Theory \& Practice in Language Studies, 3(12).

Kaloeti, A. K. (2012). Particularized Conversational Implicature In TV Series "NCIS: Season 2." LANTERN (Journal on English Language, Culture and Literature), 1(2).

Kondowe, W., Ngwira, F. F., \& Madula, P. (2014). Linguistic Analysis of Malawi Political Newspaper Cartoons on President Joyce Banda: Towards Grice's Conversational Implicature.". International Journal of Humanities and Social Science, 4(7), 40-51.

Kustantini, D. (2012). A Pragmatic Analysis of Directive Speech Acts In Alice In Wonderland Movie Script (2010) [PhD Thesis]. Universitas Muhammadiyah Surakarta.

Lestari, O. A., Sahara, R. M., Ardhini, Z. A., \& Chusna, I. (2020). Mitos dan Kritik Lingkungan dalam Film Aquaman. Buletin Al-Turas, 26(1), 85-101.

Levinson, S. C. (2000). Presumptive Meanings: The Theory of Generalized Conversational Implicature. MIT Press.

Livnat, Z. (2011). Quantity, Truthfulness and Ironic Effect. Language Sciences, 33(2), $305-315$.

Lubis, I. S. (2017). Conversational Implicatures of Indonesia Lawyers Club Program on TV ONE. CaLLs (Journal of Culture, Arts, Literature, and Linguistics), 1(2), 3244.

Martini, A. (2018). Conversational Implicature of Indonesian Students In Daily Conversation. Indonesian EFL Journal, 4(1), 93-100.

Miles, M. B., Huberman's, A. M., \& Saldaña, J. (2014). Qualitative Data Analysis: A Methods Sourcebook (Third Edition). SAGE Publications Inc.

Mohamed, K. O. S. (2016). Translation and Community Integration. Global Journal of Arts, Humanities and Social Sciences, 4(1), 53-56.

Mukaro, L., Mugari, V., \& Dhumukwa, A. (2013). Violation of Conversational Maxims in Shona. Journal of Comparative Literature and Culture (JCLC), 2(4), 161-168.

Muvida, A. N. (2015). The Conversational Implicature That is Used by the Three Main Characters in Hotel Transylvania Movie. UIN Sunan Kalijaga.

Newman, W. L. (2014). Social Research Methods: Qualitative and Quantitative Approaches. [Online]. Essex. Pearson Education.

Nugraha, R. A. (2013). Maxim Violation in Real Steel Movie: A Pragmatics Approach [PhD Thesis]. Universitas Muhammadiyah Surakarta.

Pop, A. (2010). Implicatures Derived through Maxim Flouting in Print Advertising. A Contrastive Empirical Approach. Toronto Working Papers in Linguistics, 33.

Risdianto, F. (2011). A Conversational Implicature Analysis in Oscar Wilde's Short Story "Happy Prince." Register Journal, 4(2), 196-213.

Rokhmania, N. (2012). Descriptive Analysis on Flouting and Hedging of Conversational Maxims in the "Post Grad" Movie. Register Journal, 5(2), 123-142.

Rundquist, S. (1992). Indirectness: A Gender Study of Flouting Grice's Maxims. Journal of Pragmatics, 18(5), 431-449.

Sadehvandi, P. K. N. (2011). Some instances of violation and flouting of the maxim of quantity by the main characters (Barry \& Tim) in Dinner for Schmucks. International Conference on Languages, Literature and Linguistics. P, 122-127.

Saldana, J. (2011). Fundamentals of Qualitative Research: Understanding Qualitative Research. Oxford University Press, New York.

Setiawan, S. H. (2013). An Analysis of Flouting Maxim in the Movie "the Dark Knight Rise” Based on Grice's Cooperative Principle [PhD Thesis]. PBI. 
Saiful Akmal, Desy Ulfa Yana,

Conversational Implicature Analysis in in "Kingdom of Heaven"

Sirbu, A. (2015). The significance of language as a tool of communication. Scientific Bulletin" Mircea Cel Batran" Naval Academy, 18(2), 405.

Slocum, B. G. (2016). Conversational implicatures and legal texts. Ratio Juris, 29(1), 2343.

Sobhani, A., \& Saghebi, A. (2014). The Violation of Cooperative Principles and Four Maxims in Iranian Psychological Consultation. Open Journal of Modern Linguistics, 2014.

Stemler, S. E. (2015). Content analysis. Emerging Trends in the Social and Behavioral Sciences: An Interdisciplinary, Searchable, and Linkable Resource, 1-14.

Sudarni, S. (2011). A Descriptive Study on Conversational Implicature Used in" Salt" Movie Script [PhD Thesis]. IAIN Salatiga.

Taghiyev, I. (2017). Violation of Grice's Maxims and Ambiguity in English Linguistic Jokes. International E-Journal of Advances in Social Sciences, 3(7), 284-288.

Tylén, K., Weed, E., Wallentin, M., Roepstorff, A., \& Frith, C. D. (2010). Language as a Tool for Interacting Minds. Mind \& Language, 25(1), 3-29.

Westera, M. (2013). Attention, I'm violating a maxim! 'A unifying account of the final rise. 17th Workshop on the Semantics and Pragmatics of Dialogue (DialDam).

Wilson, B. G. (1995). Metaphors for instruction: Why we talk about learning environments. Educational Technology, 35(5), 25-30.

Xiaosu, Y. (2010). Conversational implicature analysis of Humour in American situation comedy "friends" [PhD Thesis]. Ghent University, Ghent. 